\title{
Understanding of Severe Sepsis and Septic Shock Among Emergency Department and Intensive Care Unit Medical Officers in a Developing Country Nepal: A Survey Study
}

\author{
Shrestha GS,,$^{1^{*}}$ Parajuli BP, Acharya SP, Banstola A, ${ }^{2}$ Upadhyay ${ }^{1},{ }^{2}$ Bajracharya $T^{3}$
}

\begin{abstract}
Affiliation:
1. Department of Anaesthesiology, Tribhuvan University Teaching Hospital, Maharajgunj, Kathmandu.

2. Intensive Care Unit, Alka Hospital Pvt Ltd, Ekantakuna, Lalitpur.

3. Department of Anaesthesiology and Critical Care Medicine, KIST Medical College Teaching Hospital, Imadol, Lalitpur, Nepal.
\end{abstract}

\section{ARTICLE INFO \\ Article History \\ Received : 11 Sept, 2016 \\ Accepted : 10 Oct, 2016 \\ Published : $20 \mathrm{Dec}, 2016$}

(C) Authors retain copyright and grant the journal right of first publication with the work simultaneously licensed under Creative Commons Attribution License CC - BY 4.0 that allows others to share the work with an acknowledgement of the work's authorship and initial publication in this journal.

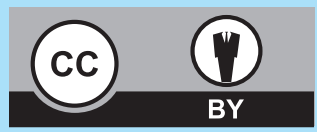

\section{* Corresponding Author}

Dr. Gentle Sunder Shrestha Intensivist \& Anaesthesiologist Department of Anaesthesiology Tribhuvan University Teaching Hospital Maharajgunj, Kathmandu, Nepal Email: gentlesunder@hotmail.com

\section{Citation}

Shrestha GS, Parajuli BP, Acharya SP, Banstola A, Upadhyay B, Bajracharya T. Understanding of Severe Sepsis and Septic Shock Among Emergency Department and Intensive Care Unit Medical Officers in a Developing Country Nepal: A Survey Study. BJHS 2016; 1 (1) 1:47-50.

\section{ABSTRACT}

\section{Introduction}

Severe sepsis and septic shock is a major cause of morbidity and mortality. The burden is higher and the outcome is dismal in the low and middle income countries.

\section{Objective}

This study aims to evaluate the knowledge about severe sepsis and septic shock among the medical officers of emergency department and intensive care unit in Nepal. It is a cross-sectional survey study.

\section{Methodology}

The medical officers working in emergency department and intensive care unit were asked to fill up the survey questionnaire, which contained the questions related to the demographics of the participant, about the knowledge of sepsis and the hindrances behind the effective management of septic patients. The percentage of correct answers for each question and average correct response for all the questions were analyzed.

\section{Results}

Seventy medical officers from twenty-four hospitals across the country were enrolled in the study. Among them, 39 were working in the emergency department and 31 were working in the intensive care unit. For the individual questions, the percentage of correct answers varied from $8.57 \%$ to $82.86 \%$ (average $48.16 \%$ ). As per the response of the participants, lack of knowledge about sepsis and management guidelines, lack of experience for management of sepsis and lack of investigation facilities were considered to be the major barriers for effective management of septic patients.

\section{Conclusions}

Knowledge and understanding about severe sepsis and septic shock among the medical officers of emergency department and intensive care unit in Nepal is sub-optimal. To improve the outcome of septic patients, efforts should be made to increase the understanding among these first-line health care workers by implementing regular and mandatory training programs.

\section{KEY WORDS}

Knowledge, medical officer, septic shock, severe sepsis 


\section{INTRODUCTION}

Sepsis is defined as the presence of probable or documented infection in conjunction with systemic manifestation of infection. Septic shock is defined as sepsis induced hypotension that persists even after adequate fluid resuscitation. ${ }^{1}$ Worldwide, the burden of sepsis is substantial. ${ }^{2}$ Largest part of the global sepsis burden occurs in middle and low income countries. Ninety percent of the worldwide deaths from pneumonia, meningitis or other infections occur in less developed countries. ${ }^{3,4}$ High incidence of bacterial, parasitic and HIV infection combined with low hygienic standards and vaccination rates, widespread malnutrition and lack of resources, explain the disproportionally high morbidity and mortality from sepsis in these countries. ${ }^{1,5}$

For most ICUs in least developed countries (LDCs), a characteristic factor limiting adequate therapy for the severely ill patient is the lack of a physician on call for 24 hours. Particularly in smaller hospitals in rural areas, physicians are only sporadically present in the ICU, and most responsibilities are left to inadequately trained medical officers or nursing personnel. Reasons for inadequate care, therefore, are not only a high workload of the physicians but also a lack of understanding about how to comprehensively care for a critically ill patient.

Emergency Department and Intensive Care Unit medical officers are usually the first line health care personnels encountering the patients with sepsis. Knowledge and awareness of sepsis among these health care personnels may play a key role in early recognition of sepsis and effective care. Even in the western world, understanding of sepsis was less among emergency medical services personnels. ${ }^{7}$ Interventions performed soon after diagnosis of sepsis have been shown to improve survival. ${ }^{8,9,10}$ This survey study aims to evaluate the knowledge of severe sepsis and septic shock among the medical officers in emergency department and intensive care unit in various cities of Nepal.

\section{METHODOLOGY}

A cross-sectional survey study was conducted among the medical officers working in intensive care unit and emergency department. The study was conducted during January to March 2016. After obtaining written informed consent, the medical officers were asked to fill up the questionnaire. A printed set of questionnaire was used for the survey, which contained the questions related to the demographics of the participant and 14 questions related to knowledge of sepsis. The last question was aimed to explore the reason behind hindrance for the management of septic patients, from the perspective of the participant. The questionnaires were based on surviving sepsis campaign international guidelines for management of severe sepsis and septic shock, 2012. ${ }^{1}$ Each of the questions had 5 options with 1 best answer. The questionnaires were pre-checked by 5 experts, not involved in the study, to ensure validity of the questions and to confirm absence of ambiguity in the multiple choices. All the experts had completed MD in Anaesthesiology and had a minimum of 2 years experience in managing the patients with severe sepsis and septic shock.

\section{RESULTS}

A total of 70 medical officers were surveyed from 24 hospitals across the country. The participating hospitals were from Kathmandu, Lalitpur, Bhaktapur, Pokhara, Lumbini and Chitwan. Among them, 39 were working in the emergency department and 31 were working in the intensive care unit.

For the individual questions, the percentage of correct answers varied from 8.57 to $82.86 \%$ with the average correct answer to be $48.16 \%$ when all the answers from all the participants were considered (Table 1).

\section{Table 1: Components in the questionnaire and the response of the participants}

\begin{tabular}{|c|c|}
\hline Components & $\begin{array}{l}\text { Correctly answered } \\
\text { n (\%) }\end{array}$ \\
\hline Definition of sepsis & $9(12.86)$ \\
\hline Criteria for organ dysfunction in severe sepsis & $29(41.43)$ \\
\hline Ideal timing to obtain blood culture in severe sepsis \& septic shock & 45 (64.29) \\
\hline Recommended target mean arterial pressure during management of Severe Sepsis \& Septic Shock & $26(37.14)$ \\
\hline Recommended target CVP for management of severe sepsis \& septic shock & 45 (64.29) \\
\hline Recommendation for completing Early Directed Goal Therapy (EGDT) & $17(24.29)$ \\
\hline Goals about timing of antibiotics administration after diagnosis of severe sepsis \&/or septic shock & $58(82.86)$ \\
\hline Recommended volume of initial fluid challenge for management of severe sepsis and septic shock & $17(24.29)$ \\
\hline Fluid of choice for management of severe sepsis/ sepsis induced hypoperfusion & $60(88.57) ।$ \\
\hline nitial vasopressor of choice for management of septic shock & 45 (64.29) \\
\hline Target goals during EGDT & $39(55.71)$ \\
\hline Indication to initiate dobutamine infusion in septic shock & $6(8.57)$ \\
\hline Indication for administration of corticosteroid for management of septic shock & $39(55.71)$ \\
\hline Advantages of managing a patient with severe sepsis as per EGDT protocol/ Surviving Sepsis Campaign Bundle & $37(52.86)$ \\
\hline All component correctly answered & $472(48.16)$ \\
\hline
\end{tabular}


Majority of the participants responded that various factors were responsible as barriers for effective management of sepsis. Lack of knowledge about sepsis and management guidelines, lack of experience for management of sepsis and lack of investigation facilities were found to be the major barriers (Table 2).

Table 2: Response of the participants about the hindrance for effective management of sepsis

\begin{tabular}{lc|}
\hline $\begin{array}{l}\text { Components } \\
\text { Lack of knowledge about sepsis and } \\
\text { management guidelines }\end{array}$ & $\begin{array}{c}\text { Correctly answered } \\
n(\%)\end{array}$ \\
\hline $\begin{array}{l}\text { Lack of experience } \\
\text { Lack of investigation facilities }\end{array}$ & $41(58.14)$ \\
\hline $\begin{array}{l}\text { Lack of central venous catheter insertion } \\
\text { facilities }\end{array}$ & $37(52.86)$ \\
\hline $\begin{array}{l}\text { Non-availability of vasopressores and } \\
\text { inotropes }\end{array}$ & $28(40.00)$ \\
\hline Non-affordability of the patients & $26(37.14)$ \\
\hline
\end{tabular}

\section{DISCUSSION}

Globally, sepsis is a leading cause of critical illness and mortality. ${ }^{11}$ Patients with sepsis and organ dysfunction have mortality that exceeds that of ST-segment elevation myocardial infarction. ${ }^{12}$ The incidence keeps increasing, with the low income countries affected the most. ${ }^{13}$ The new definition of sepsis (Sepsis-3) considers organ dysfunction as the key component of pathobiology of sepsis and is based on the retrospective review of large database. ${ }^{14,15}$ However, the definition awaits prospective validation, specially in the resource limited setting and its applicability in low-income nations still remains questionable and implementation of the new definition has yet to prove to make difference in patient management and to improve outcome. ${ }^{14,16}$ So, we conducted our study based on the definition and recommendations as suggested by surviving sepsis campaign international guidelines for management of severe sepsis and septic shock, 2012. ${ }^{1}$

Resource limited settings face several barriers for effective delivery of critical care. High cost of care is one of the main barriers. However, most cost-effective interventions like rapid fluid resuscitation, early administration of appropriate antibiotics and basic monitoring in patients with severe sepsis and septic shock are relatively inexpensive and very effective to influence outcome. As compared to the developed world, the septic patients in low-income countries are younger and with fewer comorbidities, creating a remarkable opportunity to offer a significant outcome difference by providing effective and timely care. ${ }^{17}$

Our study elucidated the fact that lack of knowledge about sepsis and its management was significant among the medical officers in emergency department and intensive care unit of various cities of Nepal. The participants also expressed that lack of knowledge and experience were the key barriers for effective management of patients with severe sepsis and septic shock. The scenario is not uncommon even in developed nations. ' Obviously, the timely and protocolized goal directed therapy or standardized care in the patients with severe sepsis and septic shock can significantly improve patient outcome. ${ }^{8,18}$ The problems attributable to significant lack of knowledge and deficiency of trained health care professionals can be overcome by training the health care professionals dealing with the patients with sepsis about the evidence based and resource-appropriate management strategies. ${ }^{17,19}$ The local professional societies and government authorities should make policies to regularly train the health care professionals about recognition and effective early management of sepsis. Local formulation and implementation of resource appropriate protocols and checklists can foster effective patient care. Attempts should be made to retain the trained experts. The focus should be to develop both short-term and long term training courses. ${ }^{20}$ Collaboration with local societies, leaders and international agents can be helpful.

There were few limitations of the study. The number of cases was limited. The level of experience of the medical officers and prior training and workshops attained were not enquired. Whether the medical officers were supervised by the intensivist, anesthesiologist or the physician was not documented. Future studies incorporating these parameters and trying to explore the effectiveness of training programs on the knowledge of medical officers, would be imperative.

\section{CONCLUSION}

Knowledge and understanding about severe sepsis and septic shock among the medical officers of emergency department and intensive care unit in Nepal is sub-optimal. To improve the outcome of septic patients, efforts should be made to increase the understanding among these first-line health care workers of the nation by implementing regular and mandatory training programs and continuing medical educations.

\section{ACKNOWLEDGEMENTS}

None

\section{CONFLICT OF INTEREST}

We declare no conflict of Interest. 


\section{REFERENCES}

1. Dellinger RP, Levy MM, Rhodes A, Annane D, Gerlach H, Opal SM, et al. Surviving sepsis campaign: international guidelines for management of severe sepsis and septic shock: 2012. Crit Care Med 2013;41:580-637.

2. Angus D, Linde-Zwirble W, Lidicker J, Clermont G, Carcillo J, Pinsky M. Epidemiology of severe sepsis in the United States; analysis of incidence, outcome, and associated cost of care. Crit Care Med 2001;29:1303-10.

3. Cheng A, West T, Limmathurotsakul D, Peacock S. Strategies to reduce mortality from bacterial sepsis in adults in adults in developing countries. PLoS Med 2008; 5:e175.

4. Silva E, Pedro Mde A, Sogayar AC, Mohovic T, Silva CL, Janiszewski M, et al. Brazilian Sepsis Epidemiology Study (BASES Study). Crit Care 2004;8:R251-60.

5. World Health Organization. The Global Burden of Disease: 2004 update. http://www.who.int /healthinfo/global_burden_disease /2004_report_update/en/index.html. Accessed April 2013.

6. Dunser MW, Baelani I, Ganbold L. A review and analysis of intensive care medicine in the least developed countries. Crit Care Med 2006;34:1234-42.

7. Seymour CW, Carlbom D, Engelberg RA, Larsen J, Bulger EM, Copass $M K$, et al. Understanding of sepsis among emergency medical services: A survey study. J Emerg Med 2012;42:666-77.

8. Rivers E, Nguyen B, Havstad S, Ressler J, Muzzin A, Knoblich B, et al. Early goal-directed therapy in the treatment of severe sepsis and septic shock. New Engl J Med 2001;345:1368-77.

9. Kumar A, Roberts D, Wood KE, Light B, Parrillo JE, Sharma S, et al. Duration of hypotension before initiation of effective antimicrobial therapy is the critical determinant of survival in human septic shock. Crit Care Med 2006;34:1589-96.

10. Gaieski DF, Mikkelsen ME, Band RA, Pine JM, Massone R, Furia FF, et al. Impact of time to antibiotics on survival in patients with severe sepsis or septic shock in whom early goal-directed therapy was initiated in the emergency department. Crit Care Med 2010; 38:1045-53.

11. Singer M, Deutschman CS, Seymour CW, Shankar-Hari M, Annane D, Bauer $\mathrm{M}$, et al. The third international consensus definitions for sepsis and septic shock (Sepsis-3). JAMA 2016;315:801-10.
12. Shah RU, Henry TD, Rutten-Ramos S, Garberich RF, Tighiouart M, Bairey Merz CN. Increasing percutaneous coronary interventions for ST-segment elevation myocardial infarction in the United States: progress and opportunity. JACC Cardiovasc Interv 2015;8:139-46.

13. Dunser MW, Festic E, Dondorp A, Kissoon N, Ganbat T, Kwizera A, et al. Recommendations for sepsis management in resource-limited settings. Intensive Care Med 2012;38:557-74.

14. Shrestha GS. Composition of the sepsis definition task force. JAMA 2016;316:459-60.

15. Shankar-Hari M, Phillips GS, Levy M, Seymour CW, Liu VX, Deutschman CS, et al. Developing a new definition and assessing new clinical criteria for septic shock: for the third international consensus definitions for sepsis and septic shock (Sepsis-3). JAMA 2016; 315:775-87.

16. Cortes-Puch I, Hartog CS. Opening the debate on the new sepsis definition. Change is not necessarily progress: Revision of the sepsis definition should be based on a new scientific insights. Am J Respir Crit Care Med 2016;194:16-8

17. Rivello ED, Letchford S, Achieng L, Newton MW. Critical care in resource-poor settings: lessons learned and future directions. Crit Care Med 2011;39:860-7.

18. Angus DC, Barnato AE, Bell D, Bellomo R, Chong CR, Coats TJ, et al. A systematic review and meta-analysis of early goal-directed therapy for septic shock: the ARISE, ProCESS and ProMISe investigators. Intensive Care Med 2015;41:1549-60.

19. Shrestha GS, Goffi A, Aryal D. Delivering neurocritical care in resourcechallenged environments. Curr Opin Crit Care 2016;22:100-5.

20. Acharya SP. Critical care medicine in Nepal: where are we ? Int Health 2013;5:92-5 